\title{
Comparison of Soil Samples from Selected Anthropogenic Sites within Enugu Metropolis for Physicochemical Parameters and Heavy Metal Levels Determination
}

\author{
Onyeka Okeke1, Ernest Ezeh², Harold Chinedu Okeke33, Charles Chukwubuikem Aniobi4, \\ Cletus Ifeanyi Akagha ${ }^{5}$
}

${ }^{1}$ Plastic Production Unit, Scientific Equipment Development Institute, Akwuke, Nigeria

${ }^{2}$ Chemical Engineering Department, Nnamdi Azikiwe University, Awka, Nigeria

${ }^{3}$ Department of Geological Sciences, Nnamdi Azikwe University, Awka, Nigeria

${ }^{4}$ Department of Community Medicine, University of Nigeria, Enugu Campus, Enugu, Nigeria

${ }^{5}$ Chemistry Department, Federal University of Technology, Owerri, Nigeria

Email: onyekaokeke207@yahoo.com

How to cite this paper: Okeke, O., Ezeh, E., Okeke, H.C., Aniobi, C.C. and Akagha, C.I. (2020) Comparison of Soil Samples from Selected Anthropogenic Sites within Enugu Metropolis for Physicochemical Parameters and Heavy Metal Levels Determination. Journal of Environmental Protection, 11, 848-861. https://doi.org/10.4236/jep.2020.1110053

Received: September 11, 2020

Accepted: October 18, 2020

Published: October 21, 2020

Copyright ( 2020 by author(s) and Scientific Research Publishing Inc. This work is licensed under the Creative Commons Attribution International License (CC BY 4.0).

http://creativecommons.org/licenses/by/4.0/ (c) (i) Open Access

\begin{abstract}
This study compared the physicochemical parameters and heavy metal levels in soil samples from selected anthropogenic sites within Enugu metropolis, Enugu State, Nigeria using standard analytical methods. Soil samples at depths $(0-20 \mathrm{~cm})$ and $(20-40 \mathrm{~cm})$ were collected from waste dump sites, metal scrap dumps, fuel filling stations and auto-mechanic workshops and analyzed for physicochemical characteristics and heavy metal levels. Atomic absorption spectrophotometer was used for heavy metal determination while conventional analytical methods were employed for physicochemical parameters evaluation of the soil samples. At soil depths $0-20 \mathrm{~cm}$ and $20-40 \mathrm{~cm}$ the respective mean range of $\mathrm{pH}$, electrical conductivity, organic matter and organic carbon contents in the soil samples were, $6.33-6.74,101.46-123.21$ $\mu \mathrm{S} / \mathrm{cm}, 6.41 \%-8.35 \%$ and $13.73 \%-16.14 \%$ for auto-mechanic workshops; $6.92-7.43,56.46-60.02 \mu \mathrm{S} / \mathrm{cm}, 1.53 \%-2.20 \%$ and $11.93 \%-12.60 \%$ for fuel filling stations; $7.14-7.84,70.81-77.71 \mu \mathrm{S} / \mathrm{cm}, 3.81 \%-4.12 \%$ and $8.57 \%-$ $9.24 \%$ for metal scrap dumps; $6.54-6.81,94.40-100.71 \mu \mathrm{S} / \mathrm{cm}, 8.83 \%$ $10.75 \%$ and $18.26 \%-20.81 \%$ for waste dump sites. The $\mathrm{pH}$ of the top soil samples from auto-mechanical workshop was below the WHO recommended limits for agricultural purposes. The physic-chemical characteristics of the soil samples decreased with soil depths indicating therefore that anthropogenic activities greatly influence the soil characteristics at the top soils than
\end{abstract}


the sub-soils. The electrical conductivity values of top and sub-soil samples from the studied auto-mechanical workshops were above the recommended limits. At soil depths $0-20 \mathrm{~cm}$ and $20-40 \mathrm{~cm}$, the respective mean range of $\mathrm{Zn}, \mathrm{Pb}$ and $\mathrm{Cd}$ in the soil samples were $17.29-19.16 \mu \mathrm{g} / \mathrm{g}, 0.704-0.96 \mu \mathrm{g} / \mathrm{g}$ and $0.26-0.33 \mu \mathrm{g} / \mathrm{g}$ for auto-mechanic workshops; $4.13-4.88 \mu \mathrm{g} / \mathrm{g}, 0.21$ $0.32 \mu \mathrm{g} / \mathrm{g}$ and $0.03-0.11 \mu \mathrm{g} / \mathrm{g}$ for fuel filling stations; $30.02-36.11 \mu \mathrm{g} / \mathrm{g}, 0.43$ $0.48 \mu \mathrm{g} / \mathrm{g}$ and $0.15-0.19 \mu \mathrm{g} / \mathrm{g}$ for metal scrap dumps; $9.30-10.84 \mu \mathrm{g} / \mathrm{g}, 0.53-$ $0.60 \mu \mathrm{g} / \mathrm{g}$ and $0.38-0.45 \mu \mathrm{g} / \mathrm{g}$ for waste dump sites. The mean levels of $\mathrm{Pb}$ in soil samples from mechanic workshops and waste dump sites were above the recommended permissible limits for agricultural purposes. The study therefore indicated that these sites (auto-mechanic workshops and waste dump sites) could be major sources of $\mathrm{Pb}$ pollution to nearby farmlands, streams and the general environment. Plants grown on or around these sites may not produce high yields and could be severely contaminated with heavy metals which portend health danger to food consumers within the environment.

\section{Keywords}

Physicochemical Parameters, Heavy Metals, Pollution, Soils, Auto-Mechanic Workshops, Fuel Filling Stations, Waste Dump Sites and Metal Scrap Dumps

\section{Introduction}

Nigeria with a land area of approximately $950,000 \mathrm{~km}^{2}$ is richly endowed with diverse resources. However, there are staggering environmental problems manifested in various forms to present a grim woes across the length and breadths of the nation. Pollution with different types of degradation such as erosion, loss of fertility and the continuing speed of urbanization are major threats to the sustainability of the environment and resources within it in Nigeria [1]. Human activities in urban areas largely contribute to the contamination of urban soils and this is a major environmental concern. Studies have shown that environmental pollution and its attendant problems on land, air and water qualities are severe now than ever [2]. There are several evidences to this fact, ranging from soil fertility loss, depletion of biodiversity, several health problems (those leading to metabolic disorder) and ecological problems.

The major causes of environmental pollution include indiscriminate discharge of wastes (solid and liquid) into natural habitats, unplanned siting of fuel filling station close to residential areas, indiscriminate dumping of wastes from auto-mechanic works, abattoirs and metal scrap outlets.

These practices are common and a disturbing trend in Nigeria, since there were well defined management protocols to regulate it. One of the major challenges confronting Nigeria as a country is solid waste management [3]. Solid wastes which are normally referred to as garbage or trash mostly contain, electronic appliances, plastics and motor oil and when undergoing decomposition or 
oxidation alters soils chemistry by releasing elements of various concentrations [4]. For instance, scrap metals are an important part of municipal solid wastes which have monetary value in Nigeria.

According to [5] scrap yards are haphazardly sited in urban centres in Nigeria where all kinds of scraps from abandoned automobiles, machineries and electrical appliances are disassembled and stacked for future recycling purpose. Many of these scrap materials are made up of contaminants that adversely affect the environment when not properly kept and managed [6].

Also, automobile emulsion is perhaps the greatest single source of contamination and it has been shown to contain lead, zinc, cadmium and nickel, the most important being lead from fuel and zinc from tyres and it accounts for about $80 \%$ of automobile pollution with heavy metals in Nigeria [7]. Repairs and servicing of automobiles and other types of machinery in mechanic workshops are sources of heavy metals in the environment. Automobile mechanic workshop wastes have been implicated for elevated concentrations of cadmium, chromium, copper, lead, nickel and zinc in the soil profile in the vicinity of automobile waste dumps in Nigeria [8].

Automobile used waste (oil) contains product sediment, water and metallic particles resulting from machinery wears, organic and inorganic chemicals used in oil additive that alters soil chemical characteristics and increase the heavy metal loads in the soil as a result of the constant and indiscriminate spewing on the soil surface of the workshops.

Open dumps are generally unsanitary and constitute malodorous places in which disease-carrying vermin such as rats and flies proliferate [9]. Methane and other gases are released into the surrounding air and micro organisms decompose the solid wastes and fires pollute the air with acrid smoke and numerous volatiles. Liquids that ooze and seep through the solid waste heap ultimately reach the soil, surface water and ground water contaminating them with organic and inorganic pollutants.

Hazardous materials such as heavy metals, pesticides and hydrocarbons that are dissolved in these liquids often contaminate solid and water [10].

According to [8], the continuous disposal of municipal waste on the soil may lead to an increase in heavy metal loads in the soil and surface water that could become inimical to deep feeding plants. Heavy metals such as arsenic, cadmium, lead, chromium, nickel, cobalt and mercury are of concern primarily because of their ability to harm soil organism, plants, animals and human beings [10]. More emphatic are the untreated dumplings' that rapidly increase soil toxicity making such large area dump sites potentially hazardous for agricultural purposes.

According to [11], fuel filling stations sited very close to residential areas and agricultural farmlands are major sources of organic and inorganic pollution of these areas due to regular discharge of petroleum products these filling stations. Most pollutants from the filing station have been known to be persistent and bioaccumlative within the environment and the potential lifelong effects resulting from these pollutants on the inhabitants of the environment and workers in 
the filling stations are already well established [12].

Most times people in the quest to obtain manure, park up soils around dump sites and other anthropogenic active environments with the hope that it would improve the soil fertility of their farmlands without equally understanding the associated negative impact of such practices on the soil chemistry and pollution index of such farmlands.

Agricultural activity around these anthropogenic sites (metal scrap dumps, metal scrap dumps, fuel filling stations, auto-mechanic workshops and waste dump sites) have not been found to aid high crop growth and yield suggesting an underlying alteration of important soil physicochemical properties occasioned by high level of pollution.

Therefore studies were carried out to evaluate the physicochemical properties and heavy metal levels in soil samples obtained in selected anthropogenic sites within Enugu metropolis, Enugu State, Nigeria, with a view to finding out the impact of such activities on the heavy metal pollution index in the soil samples within the metropolis.

\section{Materials and Methods}

\subsection{Study Area}

Enugu metropolis is made of the three local government areas, namely: Enugu South, Enugu North and Enugu East in Enugu State. These three local government areas comprised the capital of Enugu State and lie approximately in longitude $7^{\circ} 07^{\prime}$ and latitude $7^{\circ} 48^{\prime} \mathrm{N}$. Enugu metropolis is densely populated with industrial, agricultural and economic activities on the increase owing to the relative peace in the capital and the state in general. The metropolis is home to so many government offices that equally serve as the headquarters of the South East region of Nigeria. The occupations of the people are mainly trading, civil and public service work, and farming.

Due to the peaceful atmosphere in the metropolis, a lot of economic activities are going on, hence anthropogenic sites such as auto-mechanic workshops metal scrap dumps, fuel filling stations, waste dump sites, hospitals and major and street markets are common.

\subsection{Sample Location and Collection}

Four soil samples each from four anthropogenic active sites (dump sites, metal scraps yards, fuel filling station and mechanic workshops) were selected across each of the local government areas that make up the metropolis. The choice of these locations was based on their proximity to residential neighborhoods'.

In each of these selected sites, soil samples were collected using soil auger at depths of $0-20 \mathrm{~cm}$ and $20-40 \mathrm{~cm}$ representing the top and bottom soils respectively. At each selected site, the soil samples were taken from four different points and the auger borings of the same depths from the four points were bulked and representative samples gotten after series of coning and quartering. 
The soil samples were air dried ground and passed through a $2 \mathrm{~mm}$ sieve and stored in clean labeled plastic cans until analysis. Before each sampling, the surface debris on the soils was removed.

\subsection{Physicochemical Analyses of the Soil Samples}

Physicochemical parameters such as $\mathrm{pH}$ and electrical conductivity were determined using $\mathrm{pH}$ meter and conductivity meter respectively while organic matter and organic carbon contents were determined in the soil samples were determined using Walkley and Black wet oxidation procedures as described by [13] [14].

\subsection{Heavy Metal Analyses}

Exactly $5 \mathrm{~g}$ of the soil sample was weighed and $6 \mathrm{ml}$ of freshly prepared aqua regia (1:3) $\mathrm{HNO}_{3}: \mathrm{HCl}$ respectively was added and placed in a digestion block for about 30mins. It was allowed to cool and then filtered into a $100 \mathrm{ml}$ volumetric flask with distilled water. The filtrate was analyzed for selected heavy metals ( $\mathrm{Zn}$, Pd and Cd) using Perkin-Elmer Analyst 300 atomic absorption spectrophotometer (AAS).

\subsection{Contamination/Pollution Index (C/P) of the Metals}

The contamination/pollution index of the studied metals in the soil samples was calculated using the scheme formulated by [15];

$$
C / P=\frac{A}{B}
$$

where $A$ represents concentration of the metals in the soil and

$B$ represents target value.

Contamination/pollution index value greater than 1, defines pollution range but when it is less than 1 , it defines the contamination range.

Table 1. Significance of intervals of contamination/pollution index $(\mathrm{C} / \mathrm{P})$ values.

\begin{tabular}{cc}
\hline $\mathrm{C} / \mathrm{P}$ & Significance \\
\hline$<0.1$ & Very slight contamination \\
$0.10-0.25$ & Slight contamination \\
$0.26-0.50$ & Moderate contamination \\
$0.81-0.75$ & Severe contamination \\
$0.76-1.0$ & Very severe contamination \\
$1.1-2.0$ & Slight pollution \\
$2.1-4.0$ & Moderate pollution \\
$4.1-8.0$ & Severe pollution \\
$8.1-16.0$ & Very severe pollution \\
$>16$ & Excessive pollution \\
\hline
\end{tabular}

Source: [15]. 


\subsection{Statistical Analysis}

Results obtained from all samples were subjected to descriptive (mean, standard deviation and ranges) statistics.

\subsection{Quality Control}

All glass wares used were previously soaked in 14\% nitric acid for 24 hours to remove possible entrained metals, washed with detergent and rinsed with deionized water. Quality control was assured by the use of triplicates standard reference materials and procedural blanks.

\section{Results and Discussion}

\section{1. $\mathrm{pH}$}

$\mathrm{pH}$ is an important soil property, having great effects on solute concentration and adsorption in the soil. $\mathrm{pH}$ affects the mobility of heavy metals in the soil. [16] stated that soil $\mathrm{pH}$ is correlated with the availability of nutrients to the plants. Results of Table 2 show that at soil depth $0-20 \mathrm{~cm}$ and $20-40 \mathrm{~cm}$, the mean $\mathrm{pH}$ values of the soil samples were, $6.33 \pm 0.11$ and $6.74 \pm 0.08$ for auto-mechanic workshops; $6.92 \pm 0.03$ and $7.46 \pm 0.01$ for fuel filling stations; 7.14 \pm 0.12 and $7.84 \pm 0.06$ for metal scrap dumps; $6.51 \pm 0.05$ and $6.81 \pm 0.13$ for waste dump sites.

Only the pH of auto-mechanic workshop soil samples at depth of $0-20 \mathrm{~cm}$ was below the recommended permissible limits. The results of Table 2 for $\mathrm{pH}$ determination in the soil samples further show that the $\mathrm{pH}$ values of the soil samples increased with soil depth for all the investigated anthropogenic sites within Enugu metropolis. This observation therefore suggests that at the soil surface where anthropogenic activities are felt, soil chemical characteristics such as $\mathrm{pH}$ may have acidic values which lessen with soil depth occasioned by evaporation and oxidation of solutes at the soil surfaces.

Table 2. Mean physicochemical properties of the soil samples from the studied anthropogenic sites in Enugu metropolis.

\begin{tabular}{cccccc}
\hline Sample code & $\begin{array}{c}\text { Soil depth } \\
(\mathrm{cm})\end{array}$ & $\mathrm{pH}$ & $\begin{array}{c}\text { Electrical } \\
\text { conductivity }(\mu \mathrm{S} / \mathrm{cm})\end{array}$ & $\begin{array}{c}\text { Organic matter } \\
\text { content }(\%)\end{array}$ & $\begin{array}{c}\text { Organic carbon } \\
\text { content }(\%)\end{array}$ \\
\hline A.M.W & $0-20$ & $6.33 \pm 0.11$ & $123.21 \pm 2.06$ & $8.36 \pm 0.34$ & $16.14 \pm 1.15$ \\
& $20-40$ & $6.74 \pm 0.08$ & $101.46 \pm 2.13$ & $6.41 \pm 0.51$ & $13.73 \pm 0.83$ \\
& $0-20$ & $6.92 \pm 0.03$ & $60.02 \pm 164$ & $2.20 \pm 0.14$ & $12.6 \pm 0.55$ \\
F.F. S & $20-40$ & $7.46 \pm 0.12$ & $56.46 \pm 1.06$ & $1.53 \pm 0.10$ & $11.93 \pm 0.41$ \\
M.S.D & $0-20$ & $7.14 \pm 0.02$ & $77.71 \pm 1.76$ & $4.12 \pm 0.09$ & $9.24 \pm 0.17$ \\
& $20-40$ & $7.84 \pm 0.06$ & $70.84 \pm 1.51$ & $3.81 \pm 0.11$ & $8.57 \pm 0.23$ \\
W.D.S & $0-20$ & $6.54 \pm 0.05$ & $100.71 \pm 1.76$ & $10.75 \pm 0.31$ & $20.81 \pm 0.16$ \\
& $20-40$ & $6.81 \pm 0.13$ & $94.4 \pm 2.26$ & $8.83 \pm 0.19$ & $18.26 \pm 0.72$ \\
Permissible & & $6.5-8.5$ & 100 & 50 & 50 \\
limits [17] & & & & &
\end{tabular}


At the determined soil depths, the $\mathrm{pH}$ of soil samples at the studied auto-mechanical workshops were most acidic, followed by waste dump sites, fuel filling stations and metal scrap dumps. The varying anthropogenic activities within the different investigated sites could have significantly influenced the $\mathrm{pH}$ values observed for the soil samples.

[18] obtained a comparable $\mathrm{pH}$ value for soil samples on metal scrap dumps in Abraka and Agbor in Delta state with what was reported for soil samples from metal scrap dumps in this study.

At soil depths of $0-15 \mathrm{~cm}$ and $15-30 \mathrm{~cm}$, [19] obtained lower $\mathrm{pH}$ values of 3.6 and 5.4 respectively in soil samples from auto-mechanic workshops in Abra$\mathrm{ka}$, Delta state than what was obtained at soil depth of $0-20 \mathrm{~cm}$ and $20-40 \mathrm{~cm}$ in the soil samples from auto-mechanic workshops in this study. The lower $\mathrm{pH}$ values in soil samples in the auto-mechanic workshops compared to the other studied sites could be attributed to anthropogenic activities in such environment such as spilling up of acid on the soil from discharged motor batteries and spilling of fuel on the soil during routine maintenance and repair activities. Again, the low $\mathrm{pH}$ values observed for soil samples in the mechanic workshops and waste dump sites could be as a result of a higher decomposition of organic matter in these sites which then releases carbon IV oxide that reacts with water to form carbonic acid, which eventually reduces soil $\mathrm{pH}$.

\subsection{Electrical Conductivity $(\mu \mathrm{S} / \mathrm{cm})$}

Results of Table 2 show that at soil depths $0-20 \mathrm{~cm}$ and $20-40 \mathrm{~cm}$, the mean electrical conductivity of the soil samples were, $123.21 \pm 2.06$ and $101.46 \pm 2.15$ $\mu \mathrm{S} / \mathrm{cm}$ for auto-mechanic workshops; $60.02 \pm 1.64$ and $56.46 \pm 1.06 \mu \mathrm{S} / \mathrm{cm}$ for fuel filling stations; $77.71 \pm 1.76$ and $70.84 \pm 1.51 \mu \mathrm{S} / \mathrm{cm}$ for metal scrap dumps and $100.71 \pm 1.76$ and $94.40 \pm 2.26 \mu \mathrm{S} / \mathrm{cm}$ for waste dump sites.

The soil samples from auto-mechanic workshops at depths of $0-20 \mathrm{~cm}$ and $20-40 \mathrm{~cm}$ and waste dump site at $0-20 \mathrm{~cm}$ soil depth were above the WHO recommended permissible limits. The electrical conductivity values of the soil samples at the studied sites were found to decrease with depth. The studied sites had electrical conductivity values in the following decreasing order; auto-mechanic workshops $>$ waste dump sites $>$ metal scrap dumps $>$ fuel filling stations. According to [20] the implication of high electrical conductivity in soils is that there is reasonable or significant presence of ions in such soils. The higher electrical conductivity values observed for soil samples from the auto- mechanic workshops within the metropolis could be attributed to reactions between some spilled acids from motor batteries and some metals from vehicle scraps leading to the formation of some soluble and ionizable inorganic salts in the soils. Equally the build-up of degradable wastes in the soils in auto-mechanic workshops and waste dump wastes could have accounted for their observed higher values of electrical conductivity than in other studied sites. [19] reported a higher value of 202.0 to $478.0 \mu \mathrm{S} / \mathrm{cm}$ for electrical conductivity in soil samples from auto-mechanic workshops in Abraka, Delta state than what was obtained in soil 
samples from auto-mechanic workshops in this study.

[5] obtained a higher mean range of $870.00-1480.00 \mu \mathrm{S} / \mathrm{cm}$ for electrical conductivity in soil samples in metal scrap yards in Benin City, Edo State than was reported in soil samples from the metal scrap dumps in this study.

The marked variation in the electrical conductivity values in soil samples in the studied anthropogenic sites could be ascribed to the variations in the cation exchange capacities in the soil samples and the differing rates at which metallic salts and organic matter complexes are formed.

\subsection{Organic Matter (\%)}

Soil organic matter enhances the usefulness of soils for agricultural purposes. It supplies essential nutrients and has unexcelled capacity to hold water and absorb cations. It also functions as a source of food for soil microbes and thereby helps enhance and control their activities [10].

According to [2] soil organic matter usually acts as a store house or reservoir for most metals hence can influence their bioavailability in the soil. Results of Table 2 show that at soil depths $0-20 \mathrm{~cm}$ and $20-40 \mathrm{~cm}$, the mean organic matter contents of the soil samples were, $8.34 \pm 0.34$ and $6.41 \% \pm 0.51 \%$ for auto-mechanic workshops; $2.20 \pm 0.14$ and $1.53 \% \pm 0.10 \%$ for fuel filling stations; $4.12 \pm 0.09$ and $3.81 \% \pm 0.11 \%$ for metal scrap dumps; $10.75 \% \pm 0.31 \%$ and $8.83 \% \pm 0.19 \%$ for waste dump sites. The organic matter contents of the samples in the studied anthropogenic sites were also found to decrease with soil depth. This therefore buttresses anthropogenic activities as mostly affecting the soil surface and decreased with soil depths owing to evaporation, oxidation and leaching effects of solute in the soil.

The soil samples at waste dumps sites were found to have higher organic matter contents and this was attributed to its harboring of a more increased level of biodegradable waste than the other studied anthropogenic sites.

The soil samples from the studied anthropogenic sites had organic matter contents in the following decreasing order; waste dump sites $>$ auto mechanic workshops $>$ metal scrap dumps $>$ fuel filling stations.

The organic matter contents of the soil samples from all the studied anthropogenic sites were within the recommended permissible limits.

The low level biodegradable wastes of soil samples from metal scrap dumps and fuel filling stations occasioned by the activities in these sites could have accounted for their low organic matter values. [21] reported a higher value of $4.98 \%$ for organic matter contents for soil samples from fuel filling stations in Abeokuta than what was obtained in the soil samples from the fuel filling stations investigated in this study.

\subsection{Organic Carbon (\%)}

Results of Table 2 show that at soil depths $0-20 \mathrm{~cm}$ and $20-40 \mathrm{~cm}$, the mean organic carbon content of the samples were, $16.14 \pm 1.15$ and $13.73 \% \pm 0.83 \%$ 
for auto-mechanic workshops; $12.60 \pm 0.55$ and $11.93 \% \pm 0.41 \%$ for fuel filling stations; $9.24 \pm 0.17$ and $8.57 \% \pm 0.23 \%$ for metal scrap dumps site; $20.81 \pm 0.16$ and $18.26 \% \pm 0.72 \%$ for waste dump sites. The organic carbon contents of the soil samples from the studied anthropogenic sites were found to decrease with soil depth. Soil samples from waste dump sites had the highest organic matter contents while metal scrap dumps had the least organic carbon contents. The higher organic carbon contents in soil samples from waste dump sites and auto-mechanic workshops could be attributed to the presence of activities such as discharge of used oil, degradable and compostable substances and increased microbes in these soils.

[22] reported a lower value of $3.1 \%$ for organic carbon in waste dump sites within Kaduna metropolis than what was obtained for the soil samples from the waste dump sites in this study.

The results of organic matter content obtained by [19] for soil samples from auto mechanic workshops in Abraka, Delta state compared well with what was obtained in soil samples from auto-mechanic workshops in this study.

\subsection{Zinc}

Results of Table 3 show that at soil depths $0-20 \mathrm{~cm}$ and $20-40 \mathrm{~cm}$, the mean $\mathrm{Zn}$ levels in the soil samples were, $19.16 \pm 1.36$ and $17.29 \pm 1.21 \mu \mathrm{g} / \mathrm{g}$ for auto mechanic workshop; $4.88 \pm 0.57$ and $4.13 \pm 0.48 \mu \mathrm{g} / \mathrm{g}$ for fuel filling stations; $36.11 \pm 2.71$ and $30.02 \pm 2.12 \mu \mathrm{g} / \mathrm{g}$ for metal scrap dumps; $10.84 \pm 1.06$ and 9.30 $\pm 0.94 \mu \mathrm{g} / \mathrm{g}$ for waste dump sites. The mean levels of $\mathrm{Zn}$ in the soil samples from the studied anthropogenic sites were found to decrease with soil depth and this could be attributed to $\mathrm{Zn}$ mineralization by plants growing in the studied soils.

The mean levels of $\mathrm{Zn}$ in the soil samples from the studied sites were within permissible limits.

Soil samples from metal scrap sites were found to contain the highest mean levels of $\mathrm{Zn}$ of the four studied anthropogenic sites and this could be attributed

Table 3. Mean heavy metal levels in the soil samples from the studied anthropogenic sites within Enugu metropolis.

\begin{tabular}{ccccc}
\hline Samples code & Soil depth $(\mathrm{cm})$ & $\mathrm{Zn}(\mu \mathrm{g} / \mathrm{g})$ & $\mathrm{Pb}(\mu \mathrm{g} / \mathrm{g})$ & $\mathrm{Cd}(\mu \mathrm{g} / \mathrm{g})$ \\
\hline A.M.W & $0-20$ & $19.16 \pm 1.36$ & $0.74 \pm 0.13$ & $0.26 \pm 0.03$ \\
& $20-40$ & $17.29 \pm 1.21$ & $0.96 \pm 0.11$ & $0.33 \pm 0.10$ \\
F.F.S & $0-20$ & $4.88 \pm 0.57$ & $0.21 \pm 0.06$ & $0.08 \pm 0.01$ \\
& $20-40$ & $4.13 \pm 0.48$ & $0.32 \pm 0.10$ & $0.11 \pm 0.03$ \\
M.S.D & $0-20$ & $36.11 \pm 2.71$ & $0.43 \pm 0.14$ & $0.15 \pm 0.04$ \\
& $20-40$ & $30.02 \pm 2.12$ & $0.48 \pm 0.09$ & $0.19 \pm 0.08$ \\
W.D.S & $0-20$ & $10.84 \pm 1.06$ & $0.53 \pm 0.08$ & $0.438 \pm 0.15$ \\
& $20-40$ & $9.30 \pm 0.94$ & $0.60 \pm 0.17$ & $0.45 \pm 0.09$ \\
Permissible limits [17] & & 100 & 0.5 & 0.5 \\
\hline
\end{tabular}


to the wearing off of parts of the metal scraps as it was weighed, discarded and dumped on the soil surface. Soil samples from auto-mechanic workshops had the second highest levels of $\mathrm{Zn}$ and this was attributed to wearing off of vehicular paints, paint spray activities and wearing off of vehicular tyres during mechanical repairs in the workshop sites. The order of decrease of $\mathrm{Zn}$ levels in soil samples from the studied sites were, metal scrap dumps > auto-mechanical workshops $>$ waste dump sites $>$ fuel filling stations.

Zinc is involved in various metabolic activities of many organisms and is also one of the micro nutrients essential for normal growth, its increased level can cause many health disorders [19].

[23] stated that $\mathrm{Zn}$ can interrupt the activity in soils as it negatively influences the activity of micro organisms and earthworms, thus retarding the breakdown of organic matter. [5] reported a higher mean value of $171.97 \pm 19.11 \mu \mathrm{g} / \mathrm{g}$ for $\mathrm{Zn}$ in soil samples from metal scrap dumps in Benin City, Edo state than what was obtained for the metal in soil samples from the metal scrap dumps studied. [18] equally reported a higher mean value of $71.40 \mu \mathrm{g} / \mathrm{g}$ for $\mathrm{Zn}$ in soil samples from metal scrap dumps in Abraka and Agbo in Delta state than what this study obtained for $\mathrm{Zn}$ in soil samples from metal scrap dumps within Enugu metropolis. The variation in $\mathrm{Zn}$ levels in the compared results from literature could be attributed to varying intensification of anthropogenic activities, pattern of disposal and variation in soil types in the two environments.

\subsection{Lead}

Results of Table 3 show that at soil depths $0-20 \mathrm{~cm}$ and $20-40 \mathrm{~cm}$, the mean $\mathrm{Pb}$ levels in the soil samples were, $0.74 \pm 13$ and $0.96 \pm 0.11 \mu \mathrm{g} / \mathrm{g}$ for auto-mechanic workshops; $0.21 \pm 0.06$ and $0.32 \pm 0.10 \mu \mathrm{g} / \mathrm{g}$ for fuel filling stations; $0.43 \pm 0.14$ and $0.51 \pm 0.09 \mu \mathrm{g} / \mathrm{g}$ for metal scrap dumps; $0.53 \pm 0.08$ and $0.60 \pm$ $0.17 \mu \mathrm{g} / \mathrm{g}$ for waste dump sites. The mean levels of $\mathrm{Pb}$ in the top soil $(0-20 \mathrm{~cm})$ and subsoil (20 - 40) samples from auto-mechanic workshops and waste dump sites were above the $\mathrm{WHO}$ recommended permissible limits. The mean $\mathrm{Pb}$ levels in the soil samples from the studied sites decreased in the following order; auto-mechanic workshops $>$ waste dump sites $>$ metal scrap dumps $>$ fuel filling stations.

The findings of this study were in agreement with the reports of [19] that soil from samples from auto-mechanic workshops usually harbours high levels of $\mathrm{Pb}$ due to vehicular acid battery spills, used oil spills and metal bearing wear off during routine vehicle maintenance. The results of the study equally agree with the findings of [8], who stated that automobile workshop wastes have been implicated for elevated levels of $\mathrm{Cr}, \mathrm{Cu}, \mathrm{Pb}, \mathrm{Zn}$ as $\mathrm{Ni}$ in the soil profile in mechanic workshops in Nigeria. The levels of $\mathrm{Pb}$ in the soil samples from the studied anthropogenic sites were found to increase with soil depth and this was attributed to the non biodegradability and bio-accumulative tendency of heavy metals such as $\mathrm{Pb}$ and $\mathrm{Cd}$. 
Lead is a cumulative poison and a toxic element at elevated levels, hence, its presence at toxic levels in agricultural lands portends great danger to agricultural yield and eventually the food chain process.

\subsection{Cadmium}

Results of Table 3 show that at soil depths $0-20 \mathrm{~cm}$ and $20-40 \mathrm{~cm}$, the mean Cd levels in the soil samples were, $0.26 \pm 0.03$ and $0.33 \pm 0.10 \mu \mathrm{g} / \mathrm{g}$ for auto-mechanic workshops; $0.08 \pm 0.01$ and $0.11 \pm 0.03 \mu \mathrm{g} / \mathrm{g}$ for fuel filling stations; $0.15 \pm 0.04$ and $0.19 \pm 0.08 \mu \mathrm{g} / \mathrm{g}$ for metal scrap dumps; $0.38 \pm 0.15$ and $0.45 \pm$ $0.09 \mu \mathrm{g} / \mathrm{g}$ for waste dump sites. The mean Cd levels in the soil samples from the studied anthropogenic sites were within the WHO recommended permissible limits for a soil used for agricultural purposes. The mean Cd levels in the soil samples from the studied sites decreased as follows; waste dump sites > auto mechanic workshops $>$ metal scrap dumps $>$ fuel filling stations. The levels of $\mathrm{Cd}$ in the soil samples from the studied anthropogenic sites were found to increase with soil depths.

The findings of this study compared very well with the reports of [24] who observed an increase in Cd levels with soil depth in waste dump sites in Yenagoa, Bayelsa state. However, the mean levels of $\mathrm{Cd}$ in the soils from waste dump sites in Yenagoa reported by [24] was found to be lower than Cd values in the soil samples from the waste dump sites in this study and in any case both studies were in agreement in that the mean Cd levels in soil samples from the two environments were within recommended limits for an agricultural soil.

[21] attributed the high levels of $\mathrm{Cd}$ in the soils of most waste dump sites in Nigeria to the dumping of poly vinyl chloride (PVC) materials, nickel-cadmium materials and food package materials.

The mean Cd levels of $1.50 \mu \mathrm{g} / \mathrm{g}$ in soils around metal scrap dumps in Agbor and Abraka in Delta State reported by [18] were higher than what this study obtained for Cd in soil samples from metal scrap dumps within Enugu metropolis.

Results of Table 4 show the contamination factor/pollution index of the

Table 4. Contamination/pollution index of the investigated heavy metals in the soil samples from the selected anthropogenic sites within Enugu Metropolis.

\begin{tabular}{ccccc}
\hline Samples code & Soil depth $(\mathbf{c m})$ & Zn & Pb & Cd \\
\hline A.M.W & $0-20$ & 0.19 & 1.48 & 0.52 \\
& $20-40$ & 0.17 & 1.92 & 0.66 \\
F.F.S & $0-20$ & 0.05 & 0.42 & 0.16 \\
& $20-40$ & 0.04 & 0.64 & 0.22 \\
M.S.D & $0-20$ & 0.36 & 0.86 & 0.30 \\
& $20-40$ & 0.30 & 0.96 & 0.38 \\
W.D.S & $0-20$ & 0.11 & 1.06 & 0.76 \\
& $20-40$ & 0.09 & 1.20 & 0.90 \\
\hline
\end{tabular}


investigated heavy metals in the soil samples from the studied anthropogenic sites within Enugu metropolis.

Results of Table 4 shows that soil samples from auto-mechanic workshops; fuel filling stations and waste dump sites had very slight to slight contamination with $\mathrm{Zn}$. Moderate contamination with $\mathrm{Zn}$ was observed for soil samples from metal scrap dumps. [5] reported a moderate pollution of $\mathrm{Zn}$ in soil samples from metal scrap dumps in Benin Cite, Edo State and this was in contrast with the results of this study for $\mathrm{Zn}$ in soil samples from metal scraps dumps within Enugu metropolis.

Soil samples from auto-mechanical workshops and waste dump sites had a slight pollution with $\mathrm{Pb}$, where as moderate to severe contamination with $\mathrm{Pb}$ was observed for soil samples from fuel filling stations and metal scrap dumps as described in Table 1. This result therefore suggests that soils from the auto-mechanic workshops and waste dump sites would not be profitable for agricultural purposes and thus harvesting crops grown in these sites or manuring other farmland with soils from the sites could result to an increased exposure by people to $\mathrm{Pb}$ and other pollutants through the food chain process.

Table 1 shows that both the top and sub soil samples from fuel filling stations and metal scrap dumps were slight to moderately contaminate with $\mathrm{Cd}$ while severe to very severe contamination with $\mathrm{Cd}$ was observed for soil samples from auto mechanic workshops and waste dump sites within the metropolis.

Although the soils from the investigated anthropogenic sites could not be said to be polluted with $\mathrm{Cd}$ but considering the toxicity associated with this metal especially to man, edible crops grown on soils from mechanic workshops and waste dump sites still poses a very serious health risk to animals and man.

\section{Conclusions}

The results of this study show that anthropogenic sites such as auto mechanic workshops and waste dumps sites adversely affect the soil characteristics especially for agricultural purposes while fuel filling stations and metal scrap dumps do the same but to a lesser degree. In these sites, the soil characteristic of the top soils was most affected than the sub-soils suggesting; therefore anthropogenic activities adversely affect the soil characteristics of the top soil than the sub-soil.

The top and sub-soil samples from auto mechanic workshops, fuel filling stations, metal scrap dumps and waste dump sites had $\mathrm{Zn}$ and $\mathrm{Cd}$ levels within permissible limits for agricultural purposes.

The levels of $\mathrm{Pb}$ in soil samples from mechanic workshops and waste dump sites were above the permissible limit and this therefore suggests these sites as potential sources of $\mathrm{Pb}$ pollution to the surrounding agricultural farmlands and streams.

The study therefore concludes that soil samples from especially waste dump sites and auto mechanic workshops may not aid agricultural yield and edible plants grown on soils from these sites pose great health danger to food consumers. 


\section{Acknowledgements}

The authors of the research are immensely grateful to the management of Scientific Equipment Development Institute, Enugu and Nnamdi Azikiwe University, Awka, for allowing us to use their chemical laboratory for the analysis of the research samples. We equally immeasurably thank all those who one way or the other helped to make this research a great success.

\section{Conflicts of Interest}

The authors declare no conflicts of interest regarding the publication of this paper.

\section{References}

[1] Bankole, P.O. (2015) Information on Nigeria Environmental Profile. Federal Ministry of Environment, Mainframe Publishers, Abuja, 134-138.

[2] Dan, E., Fatunla, K. and Shraebu, S. (2018) Influence of Abattoir Wastes on Soil Microbial and Physicochemical Sciences. Research Journal of Chemical Sciences, 8 , 1-12. https://doi.org/10.9734/AJOCS/2018/44094

[3] Ogwuleka, T.C. (2009) Municipal Solid Waste Characteristics and Management. Iranian Journal of Environmental Health Science and Engineering, 6, 173-180.

[4] Gupta, N. and Agrawel, A.M. (2014) Characteristics and Utilization of Municipal Solid Waste of Open Dump Sites of PotiyaDurg District in India. International Journal of Innovative Research and Development, 3, 298-302.

[5] Eghomwanre, A.F., Nwosisi, M.C. and Osarenitor, O. (2019) Assessment of Heavy Metals Pollution of Surface Soil from Scrap Yards in Benin City, Nigeria. Open Access Journal of Waste Management and Xenobiotics, 2, 132-183.

[6] Adedeji, O.H., Olayinka, O.O. and Nnanya, F.C. (2014) Soil and Water Pollution Levels in and around Urban Scrap Yards. Journal of Environmental Science, Toxicology and Food Technology, 8, 1-8.

[7] Onianwa, P.C. and Fakayoda, S.O. (2010) Lead Contamination of Top Soils and Vegetation in Vicinity of Battery Factory in Nigeria. Environmental Geochemical Health, 22, 311-318.

[8] Iwegbue, C.M.A., Isirmah, N.O., Igwe, C. and William, E.S. (2006) Characteristics Levels of Heavy Metals in Soil Profile of Auto Mobile Waste Dumps in Nigeria. Environmentalist, 26, 131-137. https://doi.org/10.1007/s10669-006-7482-0

[9] Bellebaum, J. (2005) Between the Herring Gull Larusargentatus and the Bulldozer: Black Headed Gull Larus ridibundus Feeding Sites on a Refuse Dump. Ornisfennica, 82, 166-171.

[10] Adeleka, B.A. and Alawode, A.O. (2011) Contribution of Refuse Dumps to Heavy Metal Concentration in Soil Profile and Ground Water in Ibadan, Nigeria. Journal of Applied Bioscience, 40, 7237-7237.

[11] Dauda, M.S. and Odoh, R. (2012) Heavy Metals Assessment of Soil in the Vicinity of Fuel Station in Some Selected Local Government Areas of Benue Station, Nigeria. Pelagia Library, Der Chemica Sinica, 3, 1329-1336.

[12] Dara, S.S. (2000) A Textbook of Environmental Chemistry and Pollution Control. 7th Edition, S. Chand and Company Limited, New Delhi, 39-42.

[13] Chopra, C. and Kanzar, C. (1998) Analytical Agricultural Chemistry. 4th Edition, 
Prentice Hall, Charles Mail Pub. Co., Upper Saddle River, 121-125.

[14] Nelson, D.W. and Sommers, L.E. (2000) Total Carbon, Organic and Inorganic Matter. Methods of Soil Analysis Part 5, 5th Edition, Madison Publishers, Madison, 88-91.

[15] Lacatusu, R. (2000) Appraising Levels of Soil Contamination and Pollution with Heavy Metals. European Soil Research Report, 4, 393-402.

[16] Gray, W.C., Mclaren, R.G., Roberts, A.H. and Condon, M. (1998) Sorption and Desorption of Cadmium Ions from Some New Zealand Soils. Effect of $\mathrm{pH}$ and Contact Time. Australian Journal of Soil Research, 36, 199-206. https://doi.org/10.1071/S97085

[17] World Health Organization (2006) Guidelines on Trace Elements in the Soil and Food Materials. WHO, Geneva, 779-788.

[18] Akpoveta, O.V., Osakwe, S.A., Okoh, B.E. and Otuya, R.O. (2010) Physicochemical Characteristics and Heavy Metal Levels in Soils and Metal Scrap Dumps in Some Parts of Delta State, Nigeria. Journal of Applied Sciences and Environmental Management, 14, 57-60. https://doi.org/10.4314/jasem.v14i4.63258

[19] Osakwe, S.A. (2014) Heavy Metal Contamination and Physicochemical Characteristics of Soils from Automobile Workshops in Abraka, Delta State, Nigeria. International Journal of Natural Sciences Research, 2, 48-58.

[20] Fullen, M.A., Feanebough, W., Mitchel, D.L. and Truman, L.C. (2005) Resent Reclamation Using Yellow River Irrigation in Ningxia, China. Soil Use and Management, 11, 77-83. https://doi.org/10.1111/j.1475-2743.1995.tb00500.x

[21] Olayinka, O.O., Akande, O.O., Bangbose, K. and Adetungi, M.T. (2017) Physicochemical Characteristics and Heavy Metal Levels in Soils Obtained from Selected Anthropogenic Sites in Abeokuta, Nigeria. Journal of Applied Science and Environmental Management, 21, 883-891. https://doi.org/10.4314/jasem.v21i5.14

[22] Wunzani, D.K., Dada, M.S., Wyasu, G. and David, D.A.A. (2020) Assessment of Physicochemical Properties and Heavy Metal Contents in Soils from Selected Solid Waste Dump Sites in Kaduna Metropolis, Kaduna State Nigeria. Science World Journal, 15, 76-79.

[23] Wuana, R.A. and Okieimen, F.G. (2011) Heavy Metals in Contaminated Soils: A Review of Sources, Chemistry, Risk and Best Available Strategies for Remediation. International Scholarly Research Network, 29, 1913-1917. https://doi.org/10.5402/2011/402647

[24] Amos-Tautau, B., Bamidele, M.W., Ongbinde, A.O. and Ene, D. (2014) Assessment of Some Heavy Metals and Physico Chemical Properties in Surface Soils of Municipal Open Waste Dump Site in Yenagoa, Nigeria. African Journal of Environmental Science and Technology, 8, 41-47. https://doi.org/10.5897/AJEST2013.1621 